\title{
Species composition, seasonal abundance and population structure of chaetognaths in Admiralty Bay (Antarctic)
}

\author{
Luiza BIELECKA ${ }^{1 *}$, Bartłomiej JERZAK ${ }^{2}$ and Ilona $\mathrm{ZŁOCH}^{3}$ \\ ${ }^{1}$ Zakład Funkcjonowania Ekosystemów Morskich, Instytut Oceanografii, Uniwersytet Gdański, \\ al. Marszałka Pitsudskiego 46, 81-378 Gdynia, Polska \\ ${ }^{2}$ Zakład Badań Planktonu Morskiego, Instytut Oceanografii, Uniwersytet Gdański, \\ al. Marszałka Pitsudskiego 46, 81-378 Gdynia, Polska \\ ${ }^{3}$ Zakład Biologii i Ekologii Morza, Instytut Oceanografii, Uniwersytet Gdański, \\ al. Marszałka Pitsudskiego 46, 81-378 Gdynia, Polska \\ *corresponding author: ocelb@ug.edu.pl
}

\begin{abstract}
Although chaetognaths inhabiting polar ecosystems are relatively well known, there are few reports on their functioning in the Antarctic coastal plankton community. The presented results provide the first comprehensive description of population structure of chaetognaths in the neritic zone west of the Antarctic Peninsula. The studies were performed on samples collected in Admiralty Bay, from December 1994 to June 1995. Following six chaetognath species were determined: Eukrohnia hamata, E. bathypelagica, E. fowleri, Pseudosagitta gazellae, P. maxima and Solidosagitta marri. The representatives of Eukrohnia were observed almost throughout the research period, whereas those of Pseudosagitta and Solidosagitta were found only during first four months of our investigation. Eukrohnia hamata showed a strong dominance in respect to abundance (max. 445 ind. $/ 1000 \mathrm{~m}^{3}$ ). The mean abundance of all taxa significantly fluctuated in the study period and across weeks. Generally, all species were represented by the first three maturity stages (I-III), individuals stage IV occurred sporadically, and mature specimens (stage V) were not recorded at all. Morphometric analysis of the most abundant species showed distinct differences in their total length and body proportions. Our findings may suggest that chaetognath populations in Admiralty Bay are migrant, dependent on the inflow of water from the Bransfield Strait, but to prove this statement further, round year study is necessary.
\end{abstract}

Key words: Antarctic, Chaetognatha, taxa composition, population structure, body size. 


\section{Introduction}

Although Chaetognatha is a relatively small phylum consisting of 150 currently known species (Kapp 2004), they represent, in terms of abundance and biomass, one of the main zooplankton components (O'Sullivan 1982; Øresland 1990; Pierrot-Bults 2008; Kruse et al. 2009; Kruse 2010). They occupy a wide horizontal and vertical range in the world's ocean. Chaetognaths include epi-, meso- and bathypelagic species (Alvarino 1964). The species number varies from a few to ca. 30 in a given region, and is higher at lower latitudes (Alvarino 1964; Terazaki 1998; Ulloa et al. 2000; Pierrot-Bults 2008; Kruse et al. 2009). Due to their relatively low tolerance to changes in hydrological conditions, many species, including the endemic Antarctic species P. gazellae, are considered good indicators on various water masses (O'Sullivan 1982; Pierrot-Bults 2008). As main predators on copepods chaetognaths strongly influence the planktonic community and may play an important role in the whole food web (Hopkins 1985; Øresland 1990, 1995; Froneman et al. 1998; Kruse 2010; Grigor et al. 2015).

Over the last decades, studies of Chaetognatha have focused mainly on their occurrence and abundance in different regions worldwide: from the Arctic (Samemoto 1987; Terazaki 1998) through the Atlantic (Pierrot-Bults 2008), the Indian Ocean (Vijayalakshmi and Gireesh 2010) and the Pacific (Alvarino 1964; Ulloa et al. 2000) to the Southern Ocean (Bielecka and Żmijewska 1993; Duro and Gili 2001; Kruse et al. 2009; Kulagin 2010). In addition, such important aspects as behaviour, feeding, position in the trophic chain, the role of individual taxa in the ecosystem functioning and the structure of local populations of the most common and most abundant species have been also investigated (Kramp 1939; Alvarino 1968; Zo 1973; Samemoto 1987; Øresland 1990, 1995; Błachowiak-Samołyk et al. 1995; Froneman and Pakhomov 1998; Terazaki 1998; Choe and Deibel 2000; Kruse et al. 2009; Kruse et al. 2010; Grigor et al. 2014; Grigor et al. 2015).

Admiralty Bay (South Shetland Islands) is a very specific coastal water body. It is particularly interesting for biological studies because of the productivity and diversity of inhabiting organisms (Kittel et al. 2001). Hitherto, investigations on the zooplankton in this bay have mainly concerned its particular components, e.g. Tintinnina (Wasik and Mikołajczyk 1992), Copepoda (Żmijewska 1992), Euphausiacea (Stępnik 1982), Ostracoda (Blachowiak-Samolyk and Angel 2007) or the whole plankton community (Menshenina and Rakusa-Suszczewski 1992; Freire et al. 1993; Siciński et al. 1996; Kittel et al. 2001). Although chaetognaths are a very important group in the Antarctic waters, one of the most numerous after copepods, the information on their biology and ecology in Admiralty Bay is still very incomplete. Therefore, 
a more comprehensive study of seasonal differentiation, abundance and population structure is needed. According to Kulagin (2010), even the description of cosmopolitan species populations found in the Antarctic waters, e.g. Eukrohnia hamata, is far from satisfactory.

The aim of the present study was to investigate in details the quantitative, qualitative and population differentiation of Chaetognatha inhabiting Admiralty Bay, i.e. the marine coastal area with specific water circulation during the Antarctic summer and winter (1994/1995). Additionally, the detailed morphometric analysis of individual taxa was also conducted as a step towards the advancement of knowledge on Antarctic Chaetognatha.

\section{Study area}

Admiralty Bay (Fig. 1) is the largest bay of the King George Island, with an area of $122.08 \mathrm{~km}^{2}$ and the maximum depth of ca $500 \mathrm{~m}$. The bay is a fiord branching into smaller inlets: Ezcurra, MacKellar and Martel. It opens to the Bransfield Strait through wide outlet (Rakusa-Suszczewski 1995). At the exit of the bay, the depths reach the border of the shelf and farther in the Bransfield Strait, the bottom falls steeply to about 2000 m (Rakusa-Suszczewski 1980).

There are two main factors inducing a two-phase water circulation in Admiralty Bay: deep-water currents transporting water into the bay and surface currents pushing water out of the bay towards the Bransfield Strait (Robakiewicz and Rakusa-Suszczewski 1999). The entire water exchange at the surface $100 \mathrm{~m}$ layer lasts for about 2 weeks (Pruszak 1980). Due to its high dynamic the water is well mixed, so neither halocline nor thermocline could be distinguished (Szafrański and Lipski 1982).

In the central part of Admiralty Bay, during the research (between December $12^{\text {th }} 1994$ and June $11^{\text {th }} 1995$ ), the largest amplitude of water temperature fluctuation was noted at $4 \mathrm{~m}$ depth (from $-1.74^{\circ} \mathrm{C}$ to $1.71^{\circ} \mathrm{C}$ ), and the most stable temperature was found at $100 \mathrm{~m}$ depth (from $-0.83^{\circ} \mathrm{C}$ to $1^{\circ} \mathrm{C}$ ) (Fig. 2) (Rakusa-Suszczewski 1996). There was no ice cover during the observation period (Rakusa-Suszczewski 1996). Due to the lack of current measurements of salinity, consistent values from the previous studies were used (Szafrański and Lipski 1982; Rakusa-Suszczewski 1996). The authors showed that the salinity in Admiralty Bay and in the Bransfield Strait (1979-1988) increased with depth and was higher in spring (about $34 \%$ at the surface and $34.5 \%$ at a depth of $450 \mathrm{~m}$ ) compared to summer (about 33.85\% at the surface and 34.56\% at a depth of 450 m) (Szafrański and Lipski 1982; Rakusa-Suszczewski 1996). 


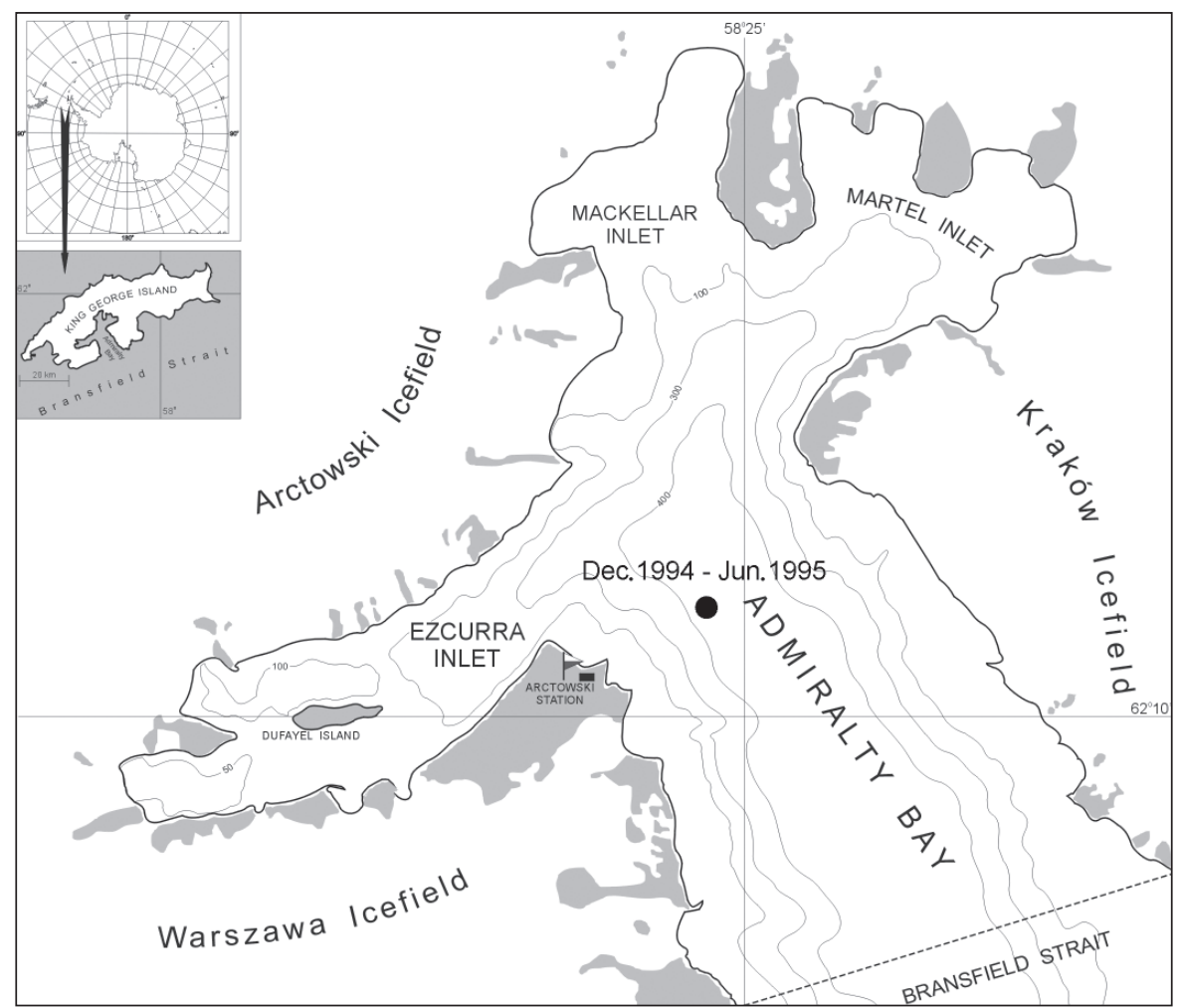

Fig. 1. Study area - Admiralty Bay (King George Island).

Sampling point coordinates: $62^{\circ} 08^{\prime} 20^{\prime \prime} \mathrm{S} ; 58^{\circ} 26^{\prime} 30^{\prime \prime} \mathrm{W}$.

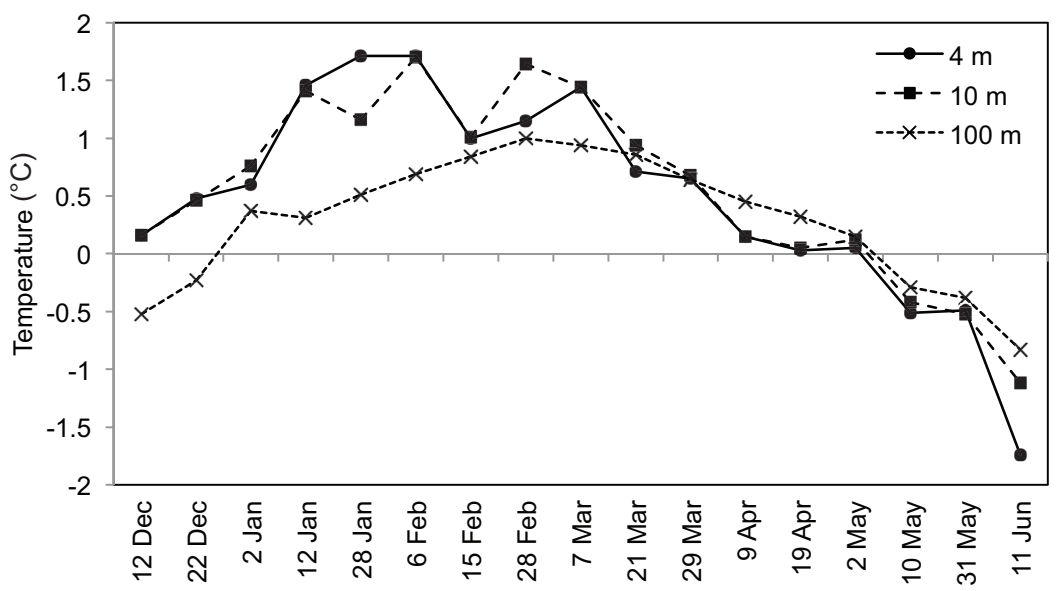

Fig. 2. Water temperature during study period (from December 1994 to June 1995) at different depths (Rakusa-Suszczewski 1996, modified). 


\section{Material and methods}

Plankton research was conducted during the 19th Polish expedition organized by the Department of Antarctic Biology (Polish Academy of Sciences). Zooplankton material was collected between austral summer 1994 and winter 1995 at a single point located in the centre of Admiralty Bay (Fig. 1, Table 1). The whole sampling was carried out from the fishing boat Słon Morski using a vertical plankton net $(\varnothing 1 \mathrm{~m}$; mesh size $335 \mu \mathrm{m})$. A total of 47 samples were collected during 17 research days between a depth of $420 \mathrm{~m}$ to the surface. The sampling frequency was one to four times per month (Table 1). The samples were immediately preserved in $4 \%$ solution of formaldehyde.

Table 1

The presence and total frequency of particular species/taxa of Chaetognatha (E. - Eukrohnia; P. - Pseudosagitta; S. - Solidosagitta)

(+ means present, - means absent).

\begin{tabular}{|c|c|c|c|c|c|c|c|c|c|c|}
\hline Date & 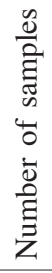 & 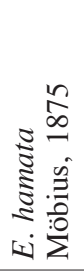 & 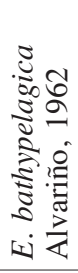 & 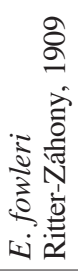 & 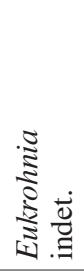 & 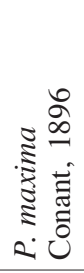 & 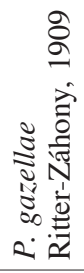 & 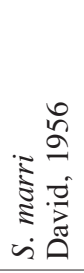 & 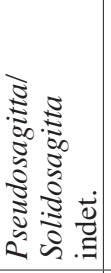 & 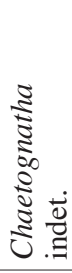 \\
\hline 12.12 .1994 & 3 & + & + & - & + & - & + & + & - & - \\
\hline 22.12 .1994 & 2 & + & - & - & + & + & + & + & + & - \\
\hline 02.01 .1995 & 2 & + & + & - & + & - & + & + & + & - \\
\hline 12.01 .1995 & 2 & + & + & - & + & - & + & + & - & - \\
\hline 28.01 .1995 & 3 & + & + & - & + & + & + & + & + & - \\
\hline 06.02 .1995 & 3 & + & + & - & + & + & + & + & + & - \\
\hline 15.02 .1995 & 3 & + & + & - & + & + & + & + & + & - \\
\hline 28.02 .1995 & 3 & + & + & - & + & + & + & + & - & - \\
\hline 07.03 .1995 & 3 & + & - & + & + & - & - & + & - & - \\
\hline 21.03 .1995 & 3 & + & - & - & - & - & - & - & - & - \\
\hline 29.03 .1995 & 3 & + & - & - & + & - & - & - & - & - \\
\hline 09.04 .1995 & 2 & + & - & + & - & - & - & - & - & - \\
\hline 19.04.1995 & 3 & - & - & - & + & - & - & - & - & + \\
\hline 02.05 .1995 & 3 & - & - & - & - & - & - & - & - & + \\
\hline 10.05 .1995 & 3 & - & - & + & - & - & - & - & - & + \\
\hline 31.05 .1995 & 3 & - & - & + & - & - & - & - & - & - \\
\hline 11.06 .1995 & 3 & + & - & - & - & - & - & - & - & - \\
\hline \multirow{2}{*}{\multicolumn{2}{|c|}{ Frequency [\%] }} & 62 & 30 & 11 & 47 & 15 & 45 & 45 & 13 & 9 \\
\hline & & \multicolumn{4}{|c|}{74} & \multicolumn{4}{|c|}{45} & \\
\hline
\end{tabular}


In the laboratory all representatives of Chaetognatha were separated from the zooplankton, counted and identified to the highest possible taxonomic level under a stereomicroscope Nikon SMZ-2T. Taxonomic identification of chaetognaths was based on the relevant literature: Dinofrio (1973), Wiktor (1973), Alvarino (1969), O'Sullivan (1982). Damaged, mostly crushed or incomplete specimens were assigned to a genus or phylum (as unidentified). In order to examine the population structure, Chaetognatha were classified into five maturity stages (I-V) using the methods described by Kramp (1939) and David (1955) (Table 2). The following parameters were measured (with the accuracy of $0.1 \mathrm{~mm}$ ) during the morphometric analysis of chaetognaths: the total organism length $\left(\mathrm{L}_{T}-\right.$ without the tail fin), head length $\left(\mathrm{L}_{\mathrm{H}}\right.$ - from the top of the head to the "neck" i.e. a narrowing between the head and the trunk), trunk length ( $\mathrm{L}_{\mathrm{Tr}}$ - from the "neck" to the crosswise septum between the tail and the trunk), length of the tail section $\left(\mathrm{L}_{\mathrm{Ta}}-\right.$ from the crosswise septum between the tail and the trunk to the tail end, without the tail fin). In total, over 4000 specimens of chaetognaths were analysed, including 2669 for sexual maturity and 2731 for morphometric parameters. Body length and maturity stage frequency distributions were binned and summarized using a percentage stacked histogram. The data are based on a single scale variable (length) and the stacks are based on categorical variable (maturity stage). All statistical analyses were carried out with Microsoft Excel, StatSoft software Statistica v.9.1 and PASW Statistics 18.

Table 2

Maturity stage classification of Eukrohnia hamata according to Kramp (1939) and Pseudosagitta gazellae according to David (1955).

Classificaton of Solidosagitta marri adopted from David (1955) for P. gazellae.

\begin{tabular}{|c|l|l|l|l|}
\hline \multirow{2}{*}{ Stage } & \multicolumn{2}{|c|}{ E. hamata } & \multicolumn{2}{c|}{ S. marri and gazellae } \\
\cline { 2 - 5 } & \multicolumn{1}{|c|}{ Male gonads } & \multicolumn{1}{|c|}{ Female gonads } & \multicolumn{1}{c|}{ Male gonads } & \multicolumn{1}{c|}{ Female gonads } \\
\hline I & Unripe & Unripe & $\begin{array}{l}\text { Tail segment empty, } \\
\text { rudiments of testes } \\
\text { present }\end{array}$ & $\begin{array}{l}\text { Ovaries not visible } \\
\text { or rudimentary }\end{array}$ \\
\hline II & $\begin{array}{l}\text { Tail containing } \\
\text { more or less sperm }\end{array}$ & All eggs small & $\begin{array}{l}\text { Tail segment } \\
\text { opaque, seminal } \\
\text { vesicles may } \\
\text { show as small } \\
\text { protuberances }\end{array}$ & $\begin{array}{l}\text { Ovaries short } \\
\text { and thin, eggs small }\end{array}$ \\
\hline III & Sperm evacuated & $\begin{array}{l}\text { All eggs small, } \\
\text { seminal receptacles } \\
\text { filled with sperm }\end{array}$ & $\begin{array}{l}\text { Seminal vesicles } \\
\text { fully formed, tail } \\
\text { segment empty }\end{array}$ & $\begin{array}{l}\text { Ovaries thin, but } \\
\text { variable in length }\end{array}$ \\
\hline IV & Sperm evacuated & $\begin{array}{l}\text { Ovaries filled with } \\
\text { ripe eggs }\end{array}$ & $\begin{array}{l}\text { Seminal vesicles } \\
\text { usually discharged }\end{array}$ & $\begin{array}{l}\text { Ovaries thick and } \\
\text { long, eggs enlarged }\end{array}$ \\
\hline V & Sperm evacuated & $\begin{array}{l}\text { Eggs evacuated, } \\
\text { receptacles still } \\
\text { containing sperm }\end{array}$ & Sperm discharged & $\begin{array}{l}\text { Eggs discharged, } \\
\text { remnants of ovaries } \\
\text { are irregular masses } \\
\text { sometimes spread } \\
\text { into the tail segment }\end{array}$ \\
\hline
\end{tabular}




\section{Results}

Species composition and abundance. - During the sampling period, chaetognaths were observed continuously in Admiralty Bay. The following six species belonging to three genera were identified: Eukrohnia hamata, Eukrohnia bathypelagica, Eukrohnia fowleri, Pseudosagitta gazellae, Pseudosagitta maxima and Solidosagitta marri (Table 1). The mean total chaetognaths abundance showed significant fluctuations (Table 3). It remained on a stable level (somewhat higher than 400 ind./1000 $\mathrm{m}^{3}$ ) during the Antarctic summer (December-February), dropped 10 times in March, reaching the value of 41 ind./1000 $\mathrm{m}^{3}$ (Table 3), while in late autumn and winter, it decreased by an order of magnitude and did not exceed 5 ind. per $1000 \mathrm{~m}^{3}$.

The representatives of the Eukrohnia genus were noted much more frequently than those of Pseudosagitta and Solidosagitta together (74\% and 45\%, respectively) (Table 1). The specimens of Eukrohnia were constant components of zooplankton (absent only at the beginning of May 1995), whereas Pseudosagitta and Solidosagitta representatives were found only during four months (December 1994 - March 1995). Within the analysed time span, the mean percentage contribution of the first genus was stable and high (from 91.8\% in December to $99.9 \%$ in March), whereas those of the second and third genera were over ten times smaller (from $8.2 \%$ in December to $0.1 \%$ in March) (Table 3). It should be mentioned that the determination of the compositions of individual Chaetognatha taxa in Admiralty Bay was based on the samples collected in the warmest period (from December to March), because of their high abundance during that period (Table 3).

Table 3

Contribution (\%) of particular chaetognaths species/taxa and mean abundance of all chaetognaths (ind./1000 $\mathrm{m}^{3}, \pm$ standard deviation) during their high abundance period ( $\mathrm{n}-$ no. of observed individuals).

\begin{tabular}{|l|c|c|c|c|}
\hline \multicolumn{1}{|c|}{ Species } & $\begin{array}{c}\text { December } \\
1994 \\
(\mathrm{n}=690)\end{array}$ & $\begin{array}{c}\text { January } \\
1995 \\
(\mathrm{n}=981)\end{array}$ & $\begin{array}{c}\text { February } \\
1995 \\
(\mathrm{n}=120)\end{array}$ & $\begin{array}{c}\text { March } \\
1995 \\
(\mathrm{n}=123)\end{array}$ \\
\hline E. bathypelagica & 1.9 & 2.1 & 1.7 & 0.0 \\
\hline E. hamata & 87.5 & 71.0 & 69.0 & 70.9 \\
\hline E. fowleri & 0.0 & 0.0 & 0.0 & 0.1 \\
\hline Eukrohnia spp. & 2.4 & 21.5 & 22.5 & 28.9 \\
\hline P. gazellae & 3.9 & 3.2 & 2.1 & 0.0 \\
\hline S. marri & 4.1 & 1.6 & 3.8 & 0.1 \\
\hline P. maxima & 0.1 & 0.2 & 0.4 & 0.0 \\
\hline Pseudosagitta/Solidosagitta spp. & 0.1 & 0.4 & 0.5 & 0.0 \\
\hline Mean abundance & $418( \pm 116)$ & $425( \pm 136)$ & $404( \pm 156)$ & $41( \pm 116)$ \\
\hline
\end{tabular}


The Eukrohnia genus was most frequently and most abundantly represented by $E$. hamata. The species was observed for most of the study period, except for period from mid-April to late May in the winter season (Table 1, Table 3). The frequency of E. hamata (62\%) was over twice as high as that of E. bathypelagica (30\%), and almost six times higher compared to E. fowleri (11\%). The monthly mean percentage contribution of $E$. hamata to the Chaetognatha population reached $87.5 \%$ in December and was not lower than $69 \%$ till the beginning of April (Table 3). The highest densities of this species were observed in Antarctic summer, its mean abundance from December to mid-February was between 445 and 239 ind./1000 $\mathrm{m}^{3}$ (Fig. 3). At that time, E. hamata also showed the greatest variability in the abundance in particular weeks - a decrease by almost $55 \%$ in the first half of January, and a similar increase between January and February. Starting from March, the mean abundance of E. hamata was definitely lower - from 89 ind./1000 $\mathrm{m}^{3}$ at the beginning of March to 1 ind./ $1000 \mathrm{~m}^{3}$ in June (Fig. 3). The next representative of the Eukrohnia genus, E. bathypelagica noted in Admiralty Bay from December to February, showed much lower and rather balanced contribution (ca. 2\%) compared to E. hamata (Table 3). It occurred in several dozen times smaller abundance - from 14 ind./1000 $\mathrm{m}^{3}$ in mid-December and late February to 2 ind./1000 $\mathrm{m}^{3}$ in mid-February (Fig. 3). The lowest percentage contribution and the lowest mean abundance within the Eukrohnia genus were observed for E. fowleri noted in Admiralty Bay from March to May (1-3 ind./1000 m³) (Table 3, Fig. 3). In May, E. fowleri was the only representative of the Eukrohnia genus (Table 1). The relatively high percentage of damaged Eukrohnia specimens was observed in the study period (from 2.4\% in December to $28.9 \%$ in March). This finding provides additional evidence for the strong dominance of the Eukrohnia genus within Chaetognatha in the study area (Table 3).

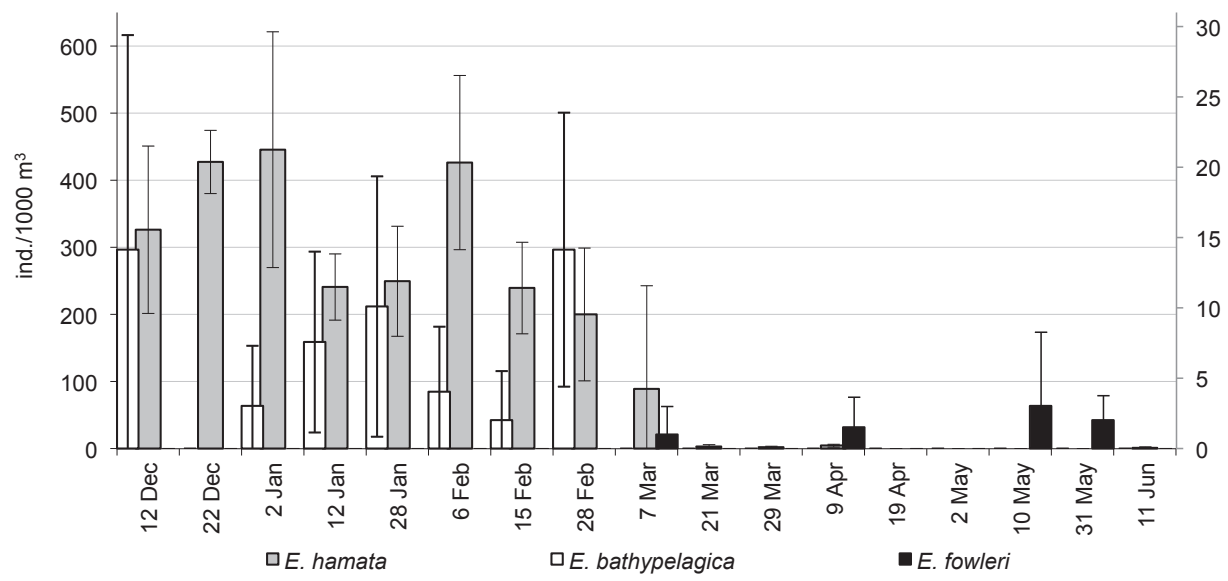

Fig. 3. Mean abundance (ind./1000 $\mathrm{m}^{3} ; \pm$ standard deviation) of Eukrohnia species during the study period (E. hamata - left Y-axis, E. bathypelagica and E. fowleri - right Y-axis). 
In Admiralty Bay, the representatives of Pseudosagitta and Solidosagitta were constantly observed from December to February (with incidence ranging from 13 to $45 \%$ ), although their abundance was much lower compared to that of the Eukrohnia species (Table 1, Fig. 4). The contribution of P. gazellae to the Chaetognatha population decreased from December to February $(3.9 \%, 3.2 \%$ and $2.1 \%$, respectively), and in December and February it was lower compared to $S$. marri (4.1\% in December, 3.8\% in February) (Table 3). The highest mean concentration of $P$. gazellae (15-18 ind./1000 $\mathrm{m}^{3}$ ) was observed from the beginning of the study till mid-January (Fig. 4). At that time, the concentration of S. marri ranged between 1 and 16 ind./1000 $\mathrm{m}^{3}$. At the end of January, mean concentrations of the above mentioned species were similarly low $\left(8\right.$ ind./1000 $\mathrm{m}^{3}$ for P. gazellae and 7 ind. $/ 1000 \mathrm{~m}^{3}$ for $S$. marri). Between February and early March, S. marri was the most abundant species from the genera of Solidosagitta and Pseudosagitta, reaching a peak at the beginning of February $\left(18\right.$ ind./1000 $\left.\mathrm{m}^{3}\right)$. Much lower concentration was recorded for P. maxima, its contribution did not exceed $0.4 \%$ of all Chaetognatha (Table 3, Fig. 4). The mean abundance of this species in December and January was almost 10 times lower compared to P. gazellae and $S$. marri, and the maximum abundance (3 ind. per $1000 \mathrm{~m}^{3}$ ) was recorded at the beginning of February (Fig. 4). The role of specimens not identified to the species level from the genus of Pseudosagitta/Solidosagitta was insignificant and their contribution did not exceed $0.5 \%$ throughout the study period (Table 3 ).

Statistical analysis of the relationship between abundance and water temperature was performed for the all analysed species, but no significant correlation (Pearson $r, p>0.05$ ) was found (E. hamata $-r=0.08, E$. bathypelagica $-r=0.09$, E. fowleri $-r=-0.27, S$. marri $-r=0.15, P$. gazellae $-r=-0.10$, P. maxima $-r=0.33$ ).

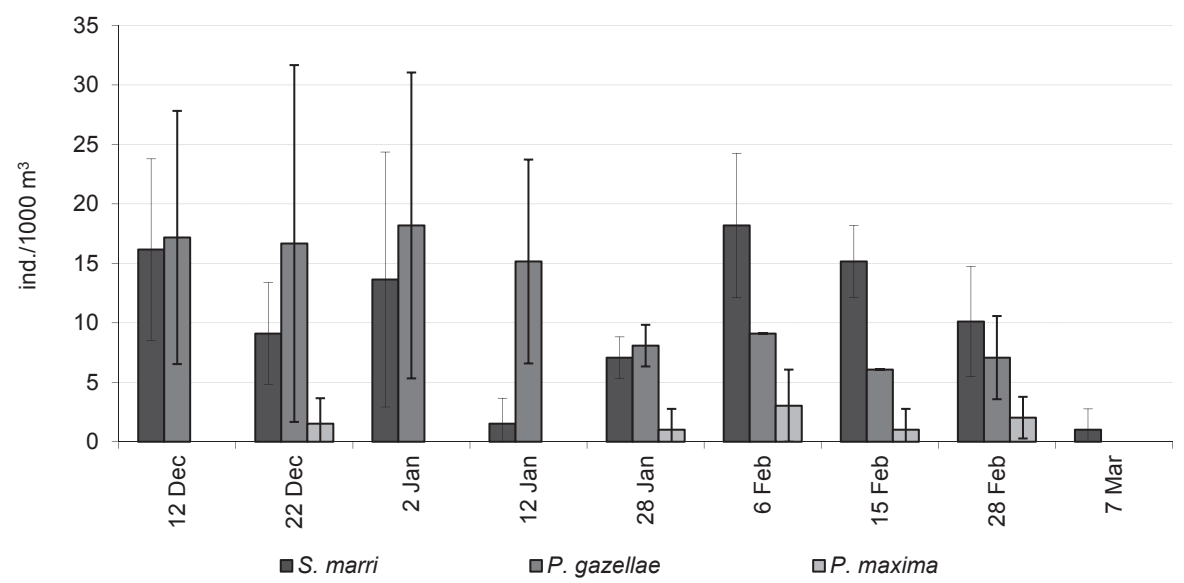

Fig. 4. Mean abundance (ind./1000 $\mathrm{m}^{3} ; \pm$ standard deviation) of Pseudosagitta and Solidosagitta species during their occurrence period. 
Morphometric data and population structure. - The number of the three most abundant species of chaetognaths in Admiralty Bay, E. hamata, P. gazellae and $S$. marri, was large enough to permit the representative analysis of morphometric features and population structure.

The E. hamata population size-frequency structure was prepared for four successive months (December 1994-March 1995) (Fig. 5). In December, the average body length of E. hamata was 10.1 ( $\mathrm{SD} \pm 3.6) \mathrm{mm}$, ranging between 2.5 and $24.7 \mathrm{~mm}$. More than $50 \%$ of the population consisted of individuals in the length interval of 5-15 mm. Among them, the individuals of $8-9 \mathrm{~mm}$ length dominated, representing over $24 \%$ of the whole population. Individuals at maturity stage I were most frequent in this month (over $85 \%$ of frequency) with the mean length of $9.1 \mathrm{~mm}( \pm 2.7)$. The second group of individuals
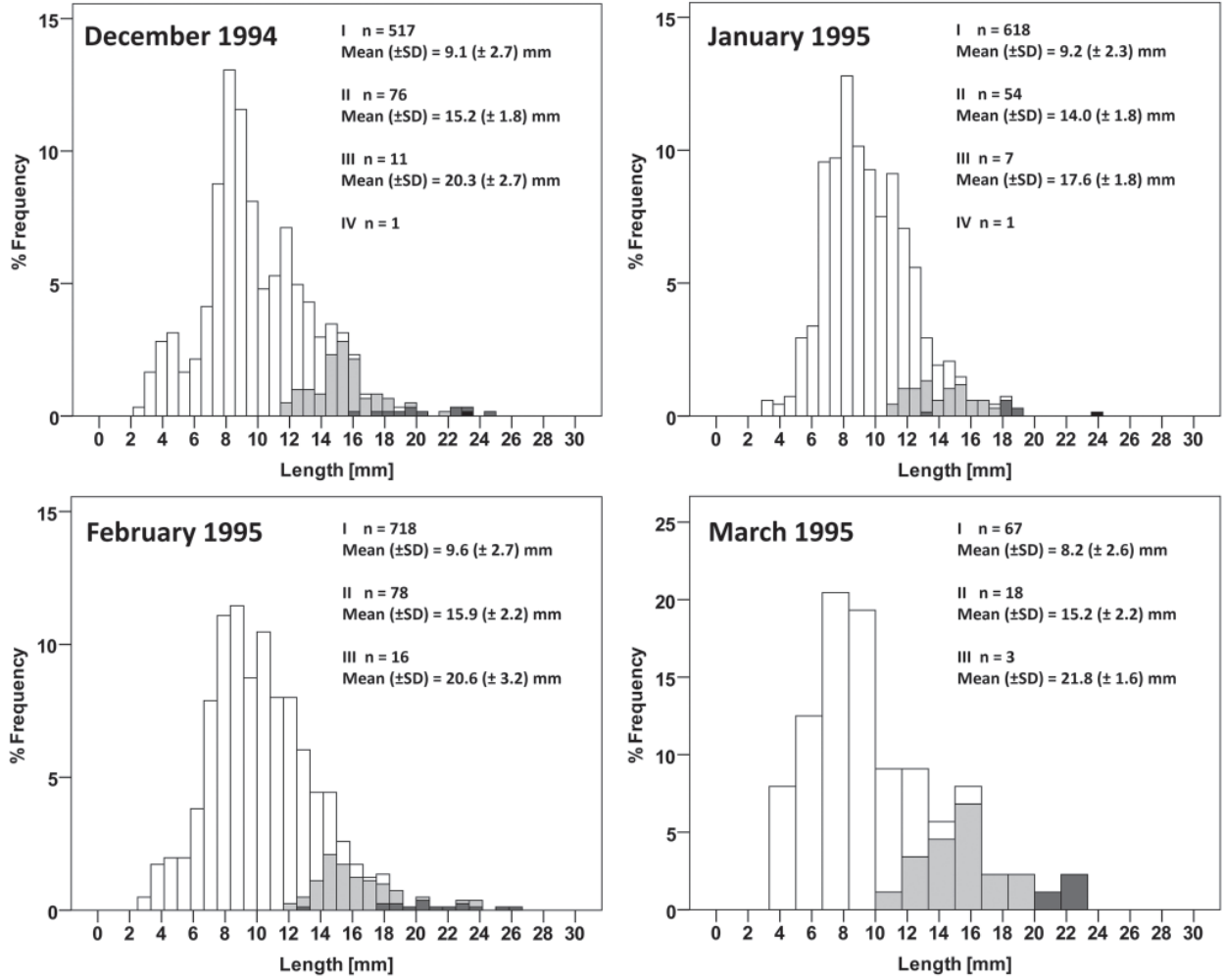

Fig. 5. Body length and life history stage frequency distribution of Eukrohnia hamata in December 1994, and January, February, March 1995 (n - no. of investigated individuals; white stage I; light gray stage II; gray stage III; black stage IV); The min and max length values for each month are: 2.5 - $24.7 \mathrm{~mm}$ (December 1994), 3.1 - $24.1 \mathrm{~mm}$ (January 1995), $3.0-26.6 \mathrm{~mm}$ (February 1995), 3.9 - $23.0 \mathrm{~mm}$ (March 1995); Total length was determined for $100 \%, 97 \%, 96 \%$ and $98 \%$, and maturity stage for $100 \%, 98 \%, 96 \%$ and $95 \%$ of E. hamata population collected in December, January, February and March, respectively. 
consisted of specimens at maturity stage II (almost 13\%) of average length $15.2 \mathrm{~mm}( \pm 1.8)$. January was a month of E. hamata dominance with the body length from 7 to $12 \mathrm{~mm}$. At the same time, a slight decrease in the number of 10-11 mm individuals was observed (Fig. 5). However, individuals from the length classes of 7 to $12 \mathrm{~mm}$ still dominated, representing almost $52 \%$ of the population. The total length of individuals analysed in January oscillated between 3.1 and $24.1 \mathrm{~mm}$, but the average value of $9.7 \mathrm{~mm}( \pm 2.8)$ was somewhat lower than in December. As in December, also in January individuals at maturity stage I, with the average length of $9.2 \mathrm{~mm}( \pm 2.3)$, were most abundant $(91 \%)$. In February, the average length of $E$. hamata individuals was $10.5( \pm 3.6) \mathrm{mm}$, whereas the minimum and maximum values were 3.0 and $26.6 \mathrm{~mm}$, respectively (Fig. 5). The maximum length $(26.6 \mathrm{~mm})$ was one of the highest recorded in the study period. Furthermore, a decrease in the contribution (by a few percent) of individuals between 6 and $12 \mathrm{~mm}$, with a simultaneous ca. 2 -fold increase in the number of organisms longer than $12 \mathrm{~mm}$ was observed. The population in this month was dominated by specimens at maturity stage I, but on average they were longer $(9.6 \pm 2.7 \mathrm{~mm})$ compared to the length of such individuals in December and January. In March, the length-frequency distribution of E. hamata individuals was slightly different (Fig. 5). There was a sharp increase in the number of $4-5 \mathrm{~mm}$ long individuals in relation to the previous month. The highest percentage contribution (almost 40\%) was found for organisms of 7-9 mm length, but their prevalence was rather low. Additionally, morphometric analysis revealed an increased contribution of individuals longer than $15 \mathrm{~mm}$. In March, the average length of organisms was $10.0( \pm 4.3) \mathrm{mm}$, and the minimum was $3.9 \mathrm{~mm}$ which was the highest value over the period of December-March. However, it should be emphasized that the number of individuals examined in March (88) was much lower than in the previous months (Fig. 5). Individuals at maturity stage I also dominated (76\%) during this month but a decrease was noted compared to previous months. What is more, a larger number of specimens at maturity stage II (20\%) and III (3\%) occurred in March compared to the period of December-February (Fig. 5).

Taking the whole study period into consideration, the population of E. hamata was dominated by the youngest individuals (stage I) (Fig. 5 and 6). When combining the length data with the maturity stages, it appears that one cohort of E. hamata could be distinguished among specimens at maturity stage I and II in December 1994, with the mean length of approximately $9 \mathrm{~mm}$. The second cohort can be distinguished from mature stage II to stage III at the length peak of approximately $12 \mathrm{~mm}$ in December 1994. However, the beginning of the population shift towards individuals at stage II and III can be observed in March (Fig. 5 and 6). In all months, the length and maturity stage of E. hamata were positively correlated (Pearson $r^{2}$ : December $r^{2}=0.58$; January $r^{2}=0.47$; Febru- 


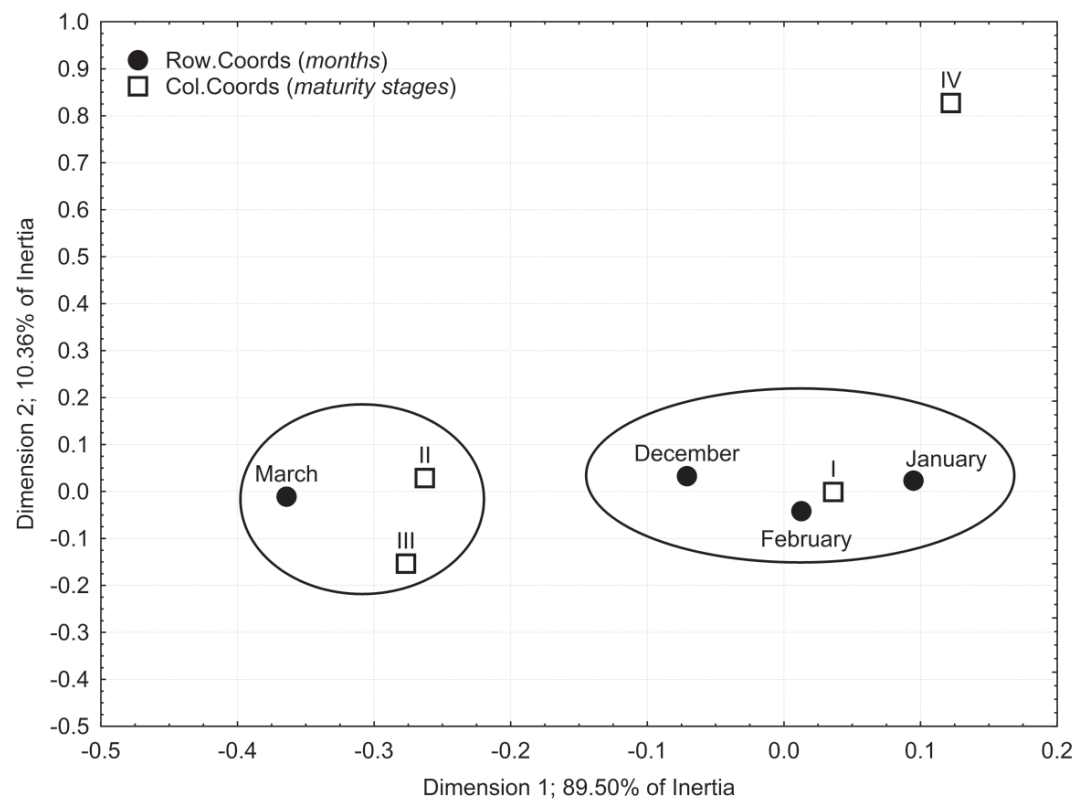

Fig. 6. Maturity stages of Eukrohnia hamata in December 1994, January, February, March 1995 (correspondence analysis; standardization: row and column profiles; rows coordination represent months, columns coordination represent maturity stages - I, II, III, and IV; inertia gives the total variance explained by each dimension in the model and represents the proportion of the total chi-square value divided by the total number of cases).

ary $r^{2}=0.50$; March $r^{2}=0.59$; for all months $p<0.05$ ). The mean length of successive maturity stages I-IV of the whole population is presented in Table 4.

Due to a relatively low abundance of $S$. marri, the population structure of this species was considered as a whole over the occurrence period (from December to March). The population was categorised into four maturity stages (I-IV) (Fig. 7, Table 4). The total length of all individuals varied from 3.0 to $15.5 \mathrm{~mm}$, with an average value of $7.4(\mathrm{SD} \pm 2.5) \mathrm{mm}$. The highest values of the size-frequency structure were shown at 5 and $8 \mathrm{~mm}$ body length represented mainly by individuals of stage I (Fig. 7). The population was dominated (75\%) by young individuals (stage I) while the contribution of other stages was much lower (ca. 13\% for stage II, 7\% for stage III and 5\% for stage IV) (Fig. 7). The mean length of individuals at successive maturity stages (I-IV) is presented in Table 4.

Similarly as in $S$. marri, the population structure of $P$. gazellae was presented for few months combined together (December-February) (Fig. 8). In Admiralty Bay, $P$. gazellae was represented by the first three maturity stages, with dominant stage I - more than $70 \%$ of the population. The length of $P$. gazellae individuals ranged broadly from 8.3 to $83.0 \mathrm{~mm}$, with an average 
Total length $(\mathrm{mm})$ of particular stages of dominant chaetognaths ( $\mathrm{n}-$ no. of measured individuals; SD - standard deviation).

\begin{tabular}{|c|c|c|c|c|c|c|c|c|c|c|c|c|c|c|c|}
\hline \multirow{2}{*}{ Stages } & \multicolumn{5}{|c|}{ E. hamata } & \multicolumn{5}{|c|}{ S. marri } & \multicolumn{5}{|c|}{ P. gazellae } \\
\hline & Min. & Max. & Mean & SD & $\mathrm{n}$ & Min. & Max. & Mean & SD & $\mathrm{n}$ & Min. & Max. & Mean & SD & $\mathrm{n}$ \\
\hline I & 2.5 & 18.9 & 9.3 & 2.6 & 1920 & 3.0 & 15.5 & 6.6 & 2.0 & 56 & 8.3 & 46.0 & 20.8 & 6.9 & 55 \\
\hline II & 10.8 & 24.0 & 15.1 & 2.1 & 226 & 6.5 & 15.0 & 9.5 & 2.8 & 10 & 21.6 & 61.5 & 40.6 & 12.9 & 16 \\
\hline III & 13.0 & 26.6 & 20.1 & 2.9 & 37 & 8.4 & 10.5 & 9.8 & 0.9 & 5 & 53.1 & 83.0 & 67.0 & 12.3 & 4 \\
\hline IV & 23.0 & 24.1 & 23.6 & 0.8 & 2 & 8.5 & 12.3 & 11.2 & 1.8 & 4 & - & - & - & - & - \\
\hline
\end{tabular}

of $27.5(\mathrm{SD} \pm 15.0) \mathrm{mm}$ (Fig. 8, Table 4). Specimens with the body length of 12-25 $\mathrm{mm}$ (mainly represented by stage I) had the greatest contribution (above $50 \%$ ) to the population. The lowest contribution (less than $4 \%$ ) was found for the individuals longer than $33 \mathrm{~mm}$ dominated by stage II and III (21\% and $5 \%$ of the population, respectively). The morphometric data for $P$. gazellae individuals at successive maturity stages (I-III) is shown in Table 4.

Besides the total body length $\left(\mathrm{L}_{\mathrm{T}}\right)$, morphometric analysis of Chaetognatha included also measurements of the head $\left(\mathrm{L}_{\mathrm{H}}\right)$, the trunk $\left(\mathrm{L}_{\mathrm{Tr}}\right)$ and the tail $\left(\mathrm{L}_{\mathrm{Ta}}\right)$ to determine the body proportions of individual species. This analysis was possible for the three most abundant species, which considerably differed in terms of body length proportions (Table 5).

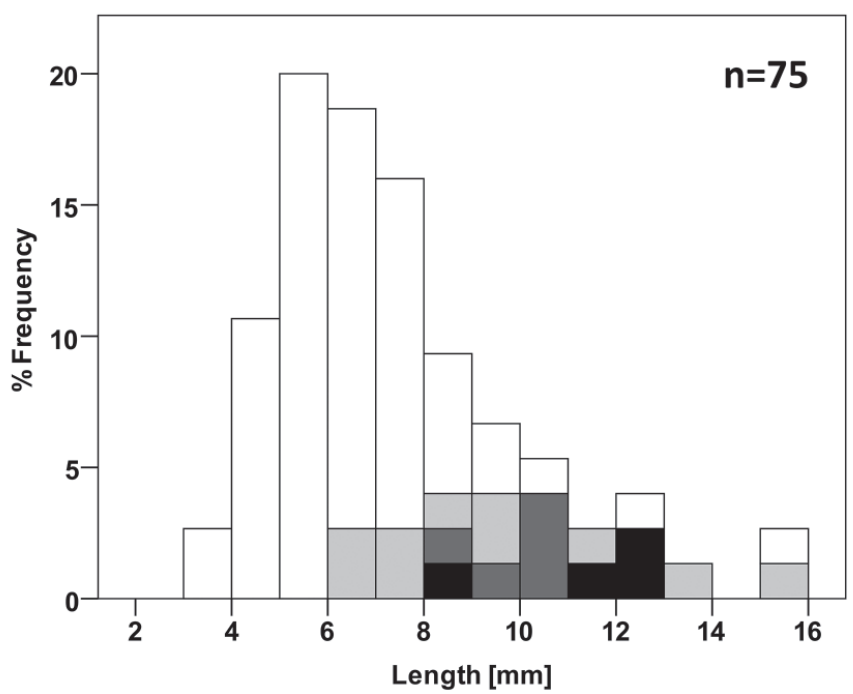

Fig. 7. Body length and maturity stage frequency distribution of Solidosagitta marri in the whole occurrence period (from December to March) (n - no. of investigated individuals; white stage I; light gray stage II; gray stage III; black stage IV); Total length was determined for 93\%, and maturity stage for $92 \%$ of total species abundance. 


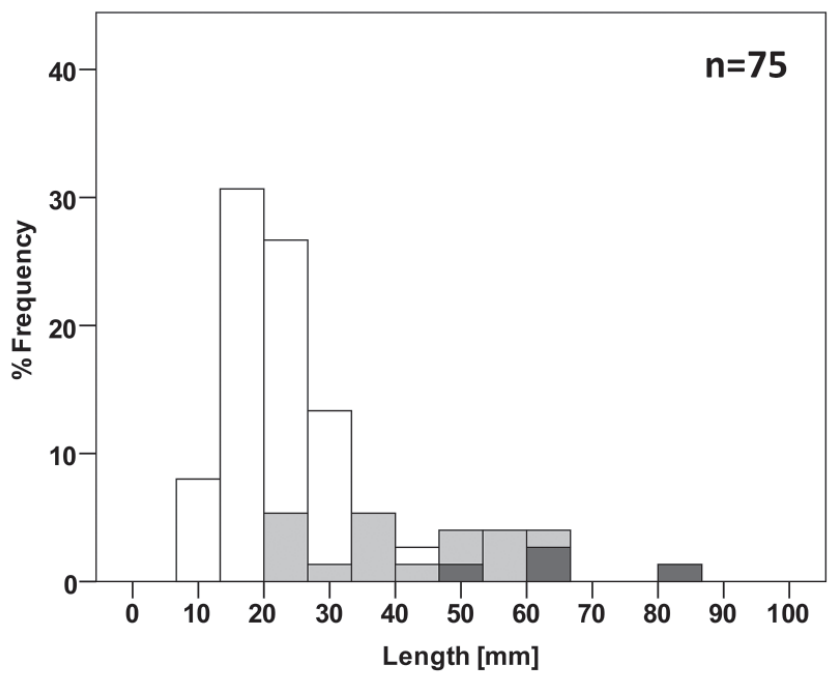

Fig. 8. Body length and maturity stage frequency distribution of Pseudosagitta gazellae in the whole occurrence period (from December to February) (n - no. of investigated individuals; white stage I; light gray stage II; gray stage III); Total length was determined for $96 \%$, and maturity stage for $94 \%$ of total species abundance.

Table 5

Morphometric characteristics (mm) of dominant chaetognaths ( $\mathrm{n}-$ no. of measured individuals; SD - standard deviation; "\%" - body proportions).

\begin{tabular}{|c|c|c|c|c|c|}
\hline \multirow{2}{*}{ Body part Parameter } & Min. & Max. & Mean & SD & $\%$ \\
\hline & \multicolumn{5}{|c|}{ E. hamata $(\mathrm{n}=2198)$} \\
\hline Total length $\left(\mathrm{L}_{\mathrm{T}}\right)$ & 2.5 & 26.6 & 10.1 & 3.4 & - \\
\hline Head length $\left(\mathrm{L}_{\mathrm{H}}\right)$ & 0.1 & 6.0 & 0.5 & 0.3 & $5 \%$ \\
\hline Trunk length $\left(\mathrm{L}_{\mathrm{Tr}}\right)$ & 1.5 & 18.8 & 7.3 & 2.5 & $73 \%$ \\
\hline \multirow[t]{2}{*}{ Tail length $\left(\mathrm{L}_{\mathrm{Ta}}\right)$} & 0.4 & 6.5 & 2.3 & 0.8 & $23 \%$ \\
\hline & \multicolumn{5}{|c|}{$P$. gazellae $(\mathrm{n}=77)$} \\
\hline Total length $\left(\mathrm{L}_{\mathrm{T}}\right)$ & 8.3 & 83.0 & 27.5 & 14.9 & - \\
\hline Head length $\left(\mathrm{L}_{\mathrm{H}}\right)$ & 0.5 & 3.8 & 1.3 & 0.8 & $5 \%$ \\
\hline Trunk length $\left(\mathrm{L}_{\mathrm{Tr}}\right)$ & 5.9 & 70.0 & 22.2 & 12.4 & $81 \%$ \\
\hline \multirow[t]{2}{*}{ Tail length $\left(\mathrm{L}_{\mathrm{Ta}}\right)$} & 1.3 & 9.5 & 4.2 & 1.7 & $15 \%$ \\
\hline & \multicolumn{5}{|c|}{ S. marri $(\mathrm{n}=77)$} \\
\hline Total length $\left(\mathrm{L}_{\mathrm{T}}\right)$ & 3.0 & 15.5 & 7.4 & 2.5 & - \\
\hline Head length $\left(\mathrm{L}_{\mathrm{H}}\right)$ & 0.3 & 1.3 & 0.6 & 0.2 & $9 \%$ \\
\hline Trunk length $\left(\mathrm{L}_{\mathrm{Tr}}\right)$ & 1.5 & 10.0 & 4.6 & 1.8 & $62 \%$ \\
\hline Tail length $\left(\mathrm{L}_{\mathrm{Ta}}\right)$ & 0.6 & 4.3 & 2.1 & 0.7 & $29 \%$ \\
\hline
\end{tabular}




\section{Discussion}

Studies of taxonomic composition, abundance and distribution of Chaetognatha in the Southern Ocean have been performed for many years. In the Atlantic sector, most of the studies have been carried out in the areas around the Antarctic Peninsula (Boysen-Ennen and Piatkowski 1988; Piatkowski 1989; Siegel and Piatkowski 1990; Bielecka and Żmijewska 1993; Øresland 1995; Kittel 1996; Duro et al. 1999; Duro and Gili 2001; Kulagin 2010). However, the research on zooplankton in Admiralty Bay has been focused on the taxa other than chaetognaths, or on the general characteristics of the whole formation (Menshenina and Rakusa-Suszczewski 1992; Wasik and Mikołajczyk 1992; Żmijewska 1992; Freire et al. 1993; Siciński et al. 1996; Kittel et al. 2001; Blachowiak-Samolyk and Angel 2007). This study provides the first comprehensive description of Chaetognatha in Admiralty Bay.

Between December 1994 and June 1995 six species of Chaetognatha were recorded in Admiralty Bay: Eukrohnia hamata, Eukrohnia bathypelagica, Eukrohnia fowleri, Pseudosagitta gazellae, Pseudosagitta maxima and Solidosagitta marri. Among them, P. gazellae and S. marri are Antarctic endemics (David 1965), whereas E. hamata is a cosmopolitan species (Alvarino 1969). In the same area (the central part of Admiralty Bay and the outlet of the bay to the Bransfield Strait) but one year earlier, Kittel et al. (2001) who made annual observations of zooplankton taxonomic composition, using a net with smaller mesh size $(200 \mu \mathrm{m})$ and similar sampling depth of $400 \mathrm{~m}$, found the same chaetognath species, except of P. maxima. Similar frequencies of S. marri, E. fowleri and E. bathypelagica were also noted, however, significant differences in the incidence of $E$. hamata (100\%) and P. gazellae (71\%) were found (Kittel et al. 2001), and one year later (this study) $-62 \%$ and $45 \%$, respectively. It could be stated that in the central part of the bay in 1993/1994 the mean abundance was higher than in the present study (331 ind./1000 m³, 205 ind./1000 m³ , respectively). Kittel et al. (2001) presented also the average abundance of individual chaetognath species: 310 ind./1000 $\mathrm{m}^{3}$ for E. hamata, 1.5 ind./1000 $\mathrm{m}^{3}$ for E. fowleri, 10 ind.$/ 1000 \mathrm{~m}^{3}$ for P. gazellae and 10 ind.$/ 1000 \mathrm{~m}^{3}$ for $S$. marri, what made $93.5 \%, 0.5 \%, 3.0 \%$ and $3.0 \%$ of the population, respectively. Our results are in accordance with the above observations. E. hamata was also found to be a dominant species with the highest percentage contribution (87.5\%) among all chaetognaths and the maximum mean abundance of 445 ind. $/ 1000 \mathrm{~m}^{3}$. It should be mentioned that the individuals of Eukrohnia, unidentified to the species level, also exhibited a relatively high percentage contribution (up to ca. 20\%). The authors believe that the representatives of $E$. hamata significantly contributed to the above group, which would confirm the prevalence of the species. The remaining species were most abundantly represented in $1994 / 1995$ by $P$. gazellae and $S$. marri with their maximum mean abundance of 18 ind./1000 $\mathrm{m}^{3}$, representing $3-4 \%$ of all 
Chaetognatha. On the other hand, E. fowleri had the lowest contribution (up to $0.1 \%$ ), with the maximum mean abundance of 5 ind./1000 $\mathrm{m}^{3}$.

There have been many reports on the abundance and species composition of Chaetognatha in the water bodies adjacent to Admiralty Bay. The research were conducted e.g. in the Gerlache Strait, which similarly as in Admiralty Bay is affected by the waters of the Bransfield Strait (Øresland 1990), in the Bransfield Strait, Drake Passage and in the Scotia Sea (Bielecka and Żmijewska 1993; Błachowiak-Samołyk et al. 1995; Duro et al. 1999; Kulagin 2010), in shelf and deep-water habitats of the Weddell Sea (Duro and Gili 2001; Boysen-Ennen and Piatkowski 1988), and in the Lazarev Sea (Kruse et al. 2009). Most of the above papers described chaetognaths in spring and summer, rarely in winter. The obtained results differ mostly in respect to the number and the list of identified species (from 2 up to 10 species). However, $E$. hamata was the most abundant in all areas (up to $95 \%$ of all chaetognaths), whereas the contribution of other species depended on the location and the study season. Kruse et al. (2009), investigating the Lazarev Sea in summer and winter, suggested that chaetognath abundance and species composition were affected by several parameters: water mass, water depth, season and ontogenesis, with the effect of water depth considered to be the major determinant. A similar trend was observed by Alvarino (1964), Bielecka and Żmijewska (1993), Błachowiak-Samołyk et al. (1995), Duro et al. (1999), Duro and Gili (2001), and Kulagin (2010). According to the researches, representatives of Chaetognatha can be found throughout the whole water column, however, they are at least several times more abundant in deep water (mainly at mesopelagic depths) than on the shelf. In addition Kruse (2010) found that chaetognaths performed seasonal vertical migrations between summer and winter, generally from shallower to greater depth in winter, probably follow migrating copepods. Our results from Admiralty Bay, which is adjacent to the Bransfield Strait, are consistent with mentioned results and confirm the typical occurrence of chaetognaths in the Antarctic waters. It could be stated that the distribution and abundance (with the significant dominance of E. hamata) of six species belonging to three genera (Eukrohnia, Pseudosagitta and Solidosagitta) confirm the thesis that the zooplankton of Admiralty Bay is influenced by the waters of the Bellingshausen and Weddell Seas. It has been previously stated by some authors (Lipski 1987; Tokarczyk 1987; Madejski and Rakusa-Suszczewski 1990) that the zooplankton may enter Admiralty Bay through the Bransfield Strait. The present authors determined strong seasonal fluctuations in the occurrence of all chaetognaths and individual species in the bay, as well as considerable differences between weeks. It also seems that the features of Chaetognatha occurring in that region - almost total absence of bathypelagic species, the level of concentration and character of variability of total and species densities - reflect the shelf character of the bay and high dynamic of its water.

The age structure of the Chaetognatha population in Admiralty Bay has not been described previously. Generally, in summer 1994/1995, most of the 
individuals from all the species was represented by the youngest stages (I-III). Stage IV occurred sporadically, and stage V was not recorded at all. Very similar features were observed for the population of E. hamata in summer in the Bransfield Strait (Błachowiak-Samołyk et al. 1995). The characteristic of the E. hamata population in Admiralty Bay, such as the lack of mature individuals and small juveniles (ca $3 \mathrm{~mm}$ ), could indicate a low level of reproduction. Simmilar observation was also made by Øresland (1990, 1995), who found that although the individuals in later stages (IV and V) occurred every month of the year, they were difficult to collect due to their very low abundance. On the other hand, the lack of fully mature individuals (among them those with brood sacs) in our study could also result from the fact that $E$. hamata reproduces at greater depths e.g. from $500 \mathrm{~m}$ to even $3000 \mathrm{~m}$ (Terazaki and Miller 1982; Øresland 1990; Kruse et al. 2009). It is widely known that the older individuals of Chaetognatha tend to prefer deeper layers of the water column, irrespective of the region (Alvarino 1964; Samemoto 1987; Øresland 1990; BłachowiakSamołyk et al. 1995; Kruse 2009). Taking into account the bathymetry, shelf character of the bay and specificity of the current system, it seems possible that we have to do with immigrant chaetognath population in Admiralty Bay.

Øresland (1990) assessed the length distribution of the E. hamata population in the Gerlache Strait and showed the lack of individuals smaller than $5 \mathrm{~mm}$, the median was between 16 and $18 \mathrm{~mm}$, while in Admiralty Bay the median ranged from 9.2 to $10.0 \mathrm{~mm}$. The maximum lengths recorded in our study for stages I-III $(18.9 \mathrm{~mm}, 24.0 \mathrm{~mm}$, and $26.6 \mathrm{~mm}$, respectively) corresponded with those reported by Øresland (1990), i.e. 17, 27, and $31 \mathrm{~mm}$. It is important for comparative purposes that the material analysed by Øresland (1990) was from a corresponding season (December-March), sampled using a net similar to that used in Admiralty Bay, and sampling depths were also similar to those in our study, i.e. from the bottom (270-500 m) to the surface. In summer 2007/2008 (November-February), Kruse et al. (2009) estimated the body length of E. hamata in the Lazarev Sea. The range for the body length was between 7 and $29 \mathrm{~mm}$ (Kruse et al. 2009), and the mean length of the individual stages was higher by 5-8 $\mathrm{mm}$ than that observed in Admiralty Bay. However, it should be noted that Kruse et al. (2009) collected their samples at greater depths, up to $3000 \mathrm{~m}$. They found that the length of animals being at the same maturity stage was greater for the bathypelagic population (Kruse et al. 2009). Such relationship was also reported by Alvarino (1964), Zo (1973), Samemoto (1987) and Øresland (1990).

The information on the population structure and the life cycle of $S$. marri and P. gazellae is definitely scarce. Kruse et al. (2009) reported that the mean body length of $S$. marri in the Lazarev Sea in summer was $6.8 \mathrm{~mm}$ and the population of this species consisted mainly of juveniles (dominance of stage I). Similar results were obtained by the present authors, however, the individuals from the Lazarev Sea population were larger (maximum up to $28 \mathrm{~mm}$ ) (Kruse 
et al. 2009) than those noted in Admiralty Bay (maximum up to $15 \mathrm{~mm}$ ). The above difference, as in the case of E. hamata, could result from the deep-water hauls taken in the Lazarev Sea. According to Kruse et al. (2009), S. marri reaches maturity at $750-1000 \mathrm{~m}$ depth. The population of $P$. gazellae in the southern part of the Drake Passage and the western part of the Bransfield Strait was previously studied by Błachowiak-Samołyk et al. (1995). Compared to the present work, they observed a significantly higher contribution of older individuals and minor abundance of juveniles in summer, but their research was not provided in the shelf waters. It was shown by Dinofrio (1973) that P. gazellae, especially its older stages, tends to prefer open waters and this fact could explain the lack of mature individuals in Admiralty Bay in summer 1994/1995. Moreover, similarly as for $S$. marri, later developmental stages of $P$. gazellae are usually found at greater depths (Alvarino 1964; Błachowiak-Samołyk et al. 1995; Duro et al. 1999). It should be added that the preservation of the samples with formaldehyde can shrink the chaetognath body length up to $3.67 \%$ in the case of E. hamata, and even up to $7.17 \%$ in the case of S. marri (Kruse et al. 2009). This may be an additional reason for observing the smaller length of organisms from Admiralty Bay.

The results of morphometric measurements presented here correspond well with the data reported by other researchers (Wiktor 1973; Dinofrio 1973; O'Sullivan 1982). However, in the majority of cases, it was not possible to determine the maximum body length reached by the studied species since the oldest developmental stages were not observed. It is interesting that the maximum length of $P$. gazellae in stage III $(83 \mathrm{~mm})$ recorded in Admiralty Bay was greater by $1 \mathrm{~mm}$ than that reported by Dinofrio (1973) and O'Sullivan (1982). The tail-to-body length ratio for almost all species presented here is close to the values found in the literature (Dinofrio 1973; O'Sullivan 1982). Our analyses showed very similar ratios of different body parts for the species from the genus Eukrohnia. The same observation was made by O'Sullivan (1982), who classified these species as one group referred to as "Eukrohnia" characterized by e.g. a similar ratio between the tail and the total body length (19-27\%) (Wiktor 1973; O'Sullivan 1982), which was confirmed also by our studies (23-26\%). Furthermore, it appears that the tail segment of $S$. marri is much longer in relation to the total body length (29\% of the body length in the individuals from Admiralty Bay) compared to the other Sagitta species. This finding was one of the reasons to include this taxon into a group called "planctonis" characterized by a relatively long tail $-20-28 \%$ of the total body length (O'Sullivan 1982). According to O'Sullivan (1982), P. maxima and P. gazellae belong to the "maxima" group which can be distinguished by a shorter relative tail length (15-19\% and up to $25 \%$ in the present results and those of O'Sullivan, respectively) and several times larger body length (over $80 \mathrm{~mm}$ ) as compared to the species from the "planctonis" group (growing up to $40 \mathrm{~mm}$ ) (Dinofrio 1973; O’Sullivan 1982). 
Unfortunately, there is no information in the available literature regarding the length of the remaining parts of the chaetognath body. The data on the ratio of the head to the total body length are limited only to general remarks (Wiktor 1973; O'Sullivan 1982). In the present work, the authors provided detailed information on the length of all parts of the body and their ratios for individual Chaetognatha taxa.

The presented study provides detailed information on the seasonal and shortterm variability in the Chaetognatha abundance in Admiralty Bay. Additional extensive data concern the nature of the population of the dominant species and basic characteristics of individual maturity stages. The authors hope that the findings will greatly contribute to a better understanding of the role of the chaetognaths in the functioning of the Antarctic neritic waters. However, further efforts should focus on examining how specific water circulation occurring in Admiralty Bay affects the distribution and abundance of these animals, as well as their populations.

Acknowledgments. - The authors thank two anonymous reviewers for their helpful and constructive suggestions. The authors would like to express their gratitude to H. Korta for collecting zooplankton samples. We also thank to Department of Antarctic Biology (Polish Academy of Science) for providing the samples.

\section{References}

Alvarino A. 1964. Bathymetric Distribution of Chaetognaths. Pacific Science 18: 64-82.

AlVARINO A. 1968. Egg Pouches and Other Reproductive Structures in Pelagic Chaetognatha. $\mathrm{Pa}$ cific Science 22: 488-492.

AlVARINO A. 1969. Los Quetognatos del Atlantico. Distribucion y notas esenciales de sistematica. Trabajos Instituto Espanol de Oceanografia 37: 1-290.

BIELECKA L. and ŻMIJEWSKA M.I. 1993. Chaetognatha of Drake Passage and Bransfield Strait (December 1983 - January - 1984, BIOMASS-SIBEX). Polish Polar Research 14: 65-74.

BLACHOWIAK-SAMOLYK K. and ANGEL M.V. 2007. A year round comparative study on the population structures of pelagic Ostracoda in Admiralty Bay (Southern Ocean). Hydrobiologia 585, 1: 67-77.

BLACHOWIAK-SAMOLYK K., BIELECKA L. and ŻMIJEWSKA M.I. 1995. Population structure of Chaetognatha in the Atlantic sector of the Southern Ocean (BIOMASS-SIBEX, December 1983 January - 1984). Polish Polar Research 16: 163-174.

Boysen-EnNen E. and PiATKowski U. 1988. Meso- and Macrozoplankton Communities in the Weddell Sea, Antarctica. Polar Biology 9: 17-35.

Choe N. and DeIBel D. 2000. Seasonal vertical distribution and population dynamics of the chaetognath Parasagitta elegans in the water column and hyperbenthic zone of Conception Bay, Newfoundland. Marine Biology 137: 847-856.

DAVID P.M. 1955. The distribution of Sagitta gazellae Ritter-Zahony.Discovery Reports 27: 235-278. DAVID P.M. 1965. The Chaetognatha of the Southern Ocean. Monograph in Biology 15: 296-323. 
DinOFRIO E.O. 1973. Resultados planctologicos de la Campana Oceantar I. 1. Quetognatos. Contibucion Del Instituto Antarctico Argentino 154: 1-62.

DURO A. and GILI J.P. 2001. Vertical distribution and abundance of juvenile Chaetognaths in the Weddell Sea (Antarctica). Polar Biology 24: 66-69.

DURO A., SABATES A. and GILI J.P. 1999. Mesoscale spatial distribution of the chaetognaths along hydrographic gradients in the South Scotia Sea (Antarctica). Polar Biology 22: 195-206.

FreIRE A.S., COELHO M.J.C. and BONECKER S.L.C. 1993. Short term spatial - temporal distribution patterns of zooplankton in Admiralty Bay (Antarctica). Polar Biology 13: 433-439.

Froneman P.W. and PAKHOMOV E.A. 1998. Trophic importance of the chaetognaths Eukrohnia hamata and Sagitta gazellae in the pelagic system of the Prince Edward Islands (Southern Ocean). Polar Biology 19: 242-249.

Froneman P.W., PAKhomov E.A., PerissinotTo R. and Meaton V. 1998. Feeding and predation impact of two chaetognath species, Eukrohnia hamata and Sagitta gazellae, in the vicinity of Marion Island (Southern Ocean). Marine Biology 131: 95-101.

GrigOR J.J., MARAIS A.E., FALK-PETERSEN S. and VARPE Ø. 2015. Polar night ecology of a pelagic predatory, the chaetognath Parasagitta elegans. Polar Biology 38: 1: 87-98.

GRIGOR J.J., SøREIDE J. and VARPE Ø. 2014. Seasonal ecology and life-history strategy of the high-latitude predatory zooplankter Parasagitta elegans. Marine Ecology Progress Series 499: $77-88$.

HoPKINS T.L. 1985. The zooplankton community of Croker Passage, Antarctic Peninsula. Polar Biology 4: 161-170.

KAPP H. 2004. Chaetognatha oder Pfeilwurmer-Leben und Entwicklung im Pelagial. Natur und Museum-Bericht der Senckenbergischen Naturforschenden Gesellschaft 134: 398-406.

KitTel W. 1996. Zooplankton wód rejonu Półwyspu Antarktycznego. Wydawnictwo UŁ, Łódź: $154 \mathrm{pp}$.

KitTel W., SicińsKi J., ŻMIJEWSKa M.I., BIELECKA L. and BŁACHOWIAK-SAMOŁYK K. 2001. Antarctic neritic zooplankton community (Admiralty Bay, King George Island, South Shetlands Islands). Polish Polar Research 22: 11-33.

KRAMP P.L. 1939. The Godthaab Expedition 1928. Chaetognatha. Meddelelser ora Gronland 80: $3-40$.

KRUSE S. 2009. Population structure and reproduction of Eukrohnia bathypelagica and Eukrohnia bathyantarctica in the Lazarev Sea, Southern Ocean. Polar Biology 32: 1377-1387.

KRUSE S. 2010. Biology of meso- and bathypelagic chaetognaths in the Southern Ocean. Reports on Polar and Marine Research 610: 145 pp.

Kruse S., BathmanN U. and Brey T. 2009. Meso- and bathypelagic distribution and abundance of chaetognaths in the Atlantic sector of the Southern Ocean. Polar Biology 32: 1359-1376.

KRUSE S., HAGEN W. and BATHMANN U. 2010. Feeding ecology and energetics of the Antarctic chaetognaths Eukrohnia hamata, E. bathypelagica and E. bathyantarctica. Marine Biology 15: 2289-2302.

Kulagin D.N. 2010. Distribution of Chaetognaths in the Central Part of the Drake Passage. Oceanology 50: 548-555.

LIPSKI M. 1987. Variation of physical conditions, nutrients and chlorophyll a contents in Admiralty Bay (King George Island, South Shetland Islands, 1979). Polish Polar Research 8: 307-332.

MADEJSKI P. and RAKUSA-SUSZCZEWSKI S. 1990. Icebergs as a tracers of water movement in the Bransfield Strait. Antarctic Science 2: 43-50.

MENSHENINA L. and RAKUSA-SUSZCZEWSKI S. 1992. Zooplankton changes during the year in Admiralty Bay (February 1990 - January 1991). Polskie Archiwum Hydrobiologii 39: 65-76. 
ØRESLAND V. 1990. Feeding and predation impact of the chaetognath Eukrohnia hamata in Gerlache Strait, Antarctic Peninsula. Marine Ecology Progress Series 63: 201-209.

ØRESLAND V. 1995. Winter population structure and feeding of the chaetognath Eukrohnia hamata and the copepod Euchaeta antarctica in Gerlache Strait, Antarctic Peninsula. Marine Ecology Progress Series 119: 77-86.

O'Sullivan D. 1982. A Guide to the Chaetognaths of the Southern Ocean and Adjacent Waters. Australian National Antarctic Research Expeditions: 58 pp.

PIATKOWSKI U. 1989. Macroplankton Communities in the Antarctic surface waters: spatial changes related to hydrography. Marine Ecology Progress Series 55: 251-259.

PIERROT-BULTS A.C. 2008. A short note on the biogeographic patterns of the Chaetognatha fauna in the North Atlantic. Deep-Sea Research II 55: 137-141.

PRUSZAK Z. 1980. Currents circulation in the waters of Admiralty Bay (region of Arctowski Station on King George Island). Polish Polar Research 1: 54-71.

RAKUSA-SUSZCZEWSKI S. 1980. Environmental conditions and the functioning of Admiralty Bay (South Shetland Islands) as a part of the near shore Antarctic ecosystems. Polish Polar Research 1: 11-27.

RAKUSA-SUSZCZEWSKI S. 1995. The hydrography of Admiralty Bay and its inlets, coves and lagoons (King George Islands, Antarctica). Polish Polar Research 16: 61-70.

RAKUSA-SUSZCZEWSKI S. 1996. Spatial and seasonal variability of temperature and salinity in Bransfield Strait and Admiralty Bay, Antarctica. Polish Polar Research 17: 29-42.

ROBAKIEWICZ M. and RAKUSA-SUSZCZEWSKI S. 1999. Application of 3D circulation model to Admiralty Bay, King George Island, Antarctica. Polish Polar Research 20: 43-58.

SAmEmoto D.D. 1987. Vertical Distribution and Ecological Significance of Chaetognaths in the Arctic Environment of Baffin Bay. Polar Biology 7: 317-328.

SiCIŃSKI J., RÓżYCKI O. and KITTEL W. 1996. Zoobenthos and zooplankton of Herve Cove, King George Island, South Shetland Islands, Antarctic. Polish Polar Research 17: 221-238.

SiEgel V. and PiATKowski U. 1990. Variability in the Macrozooplankton Community off the Antarctic Peninsula. Polar Biology 10: 373-386.

STĘPNIK R. 1982. All-year populational studies of Euphausiacea (Crustacea) in the Admiralty Bay (King George Island, South Shetland Islands, Antarctic). Polish Polar Research 3: 49-68.

SZAFRAŃSKI Z. and LIPSKI M. 1982. Characteristics of water temperature and salinity at Admiralty Bay (King George Island, South Shetland Islands, Antarctic) during austral summer 1978/1979. Polish Polar Research 3: 7-24.

TERAZAKI M. 1998. Life history, distribution, seasonal variability and feeding of the pelagic chaetognath Sagitta elegans in the Subarctic Pacific: A review. Plankton Biology and Ecology 45: $1-17$.

TERAZAKI M. and MiLleR C.B. 1982. Reproduction of Meso- and Bathypelagic Chaetognaths in the Genus Eukrohnia. Marine Biology 71: 193-196.

TOKARCZYK R. 1987. Classification of water masses in the Bransfield Strait and southern part of the Drake Passage using a method of statistical multidimensional analysis. Polish Polar Research 8: 333-366.

ULLOA R., PALMA S. and SiLVA N. 2000. Bathymetric distribution of chaetognaths and their association with water masses off the coast of Valparaiso, Chile. Deep-Sea Research I 47: 2009-2027.

VIJAYALAKSHMI R. NAIR and GIREESH R. 2010. Biodiversity of chaetognaths of the Andaman Sea, Indian Ocean. Deep-Sea Research II 57: 2135-2147.

WASIK A. and MikOŁAJCZYK E. 1992. Tintinnina. In: S. Rakusa-Suszczewski (ed.) Zatoka Admiralicji. Ekosystem strefy przybrzeżnej morskiej Antarktyki. Oficyna Wydawnicza Instytutu Ekologii PAN, Dziekanów Leśny: 141-147. 
WiKTOR K. 1973. Chaetognatha Atlantyku. Wydawnictwo UG, Gdańsk: 19 pp.

ŻMIJEWSKA M.I. 1992. Copepoda. In: S. Rakusa-Suszczewski (ed.) Zatoka Admiralicji. Ekosystem strefy przybrzeżnej morskiej Antarktyki. Oficyna Wydawnicza Instytutu Ekologii PAN, Dziekanów Leśny: 102-105.

Zo Z. 1973. Breeding and growth of the chaetognath Sagitta elegans in Bedford Basin. Limnology and Oceanography 18: 750-756.

Received 24 July 2014

Accepted 8 March 2016 